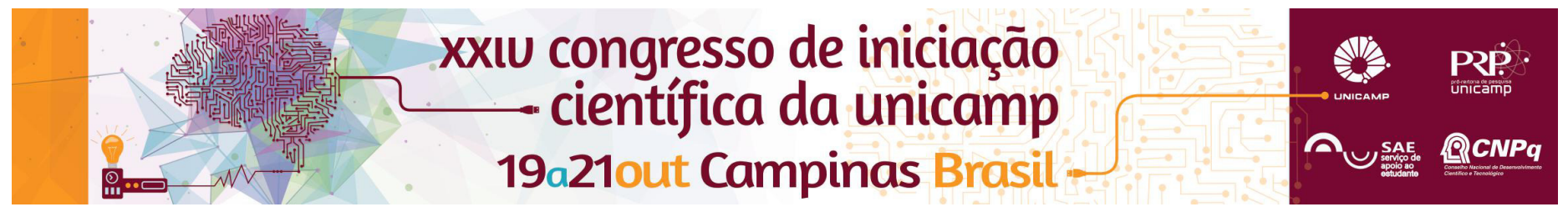

\title{
A NEUTRALIDADE DA MOEDA NA HISTÓRIA DO PENSAMENTO ECONÔMICO
}

\author{
Valdenir de Souza Dias Junior*, Adriana Nunes Ferreira.
}

\begin{abstract}
Resumo
Esta pesquisa procura entender as ideias de neutralidade e não neutralidade da moeda analisando as obras de alguns pensadores fundamentais na história do pensamento econômico, iniciando com Smith e Ricardo, representantes da chamada economia política clássica, Marshall, Fisher e Wicksell, economistas neoclássicos, e terminando com as visões alternativas aos anteriores de Marx e Keynes.
\end{abstract}

\section{Palavras-chave \\ neutralidade da moeda, história do pensamento econômico, teoria monetária}

\section{Introdução}

O surgimento das ideias que originaram a percepção das funções da moeda, o debate sobre o que cada uma delas implicam para o funcionamento das economias em geral e a influência da moeda nas decisões dos agentes e nas variáveis econômicas em geral, já foram os focos de discussões desde antes do início das teorias econômicas propriamente ditas.

Os objetivos desta pesquisa são contrastar as ideias dos autores de modo a entender o papel da moeda no sistema econômico capitalista e a pluralidade atual acerca das teorias monetárias inspiradas nas obras das referências bibliográficas.

\section{Resultados e Discussão}

Adam Smith é considerado o pai das ciências econômicas, pensador do século XVIII famoso pela obra conhecida como "A Riqueza das Nações". As ideias contidas nesse livro apontam para uma percepção de que as variáveis monetárias não afetariam as variáveis reais, ou seja, ele seria um defensor da ideia de neutralidade da moeda.

Apesar da clareza em relação à sua posição, há um prolífico debate acerca do porquê que Smith não introduziu em seu esquema teórico o mecanismo chamado price-specie-flow, de autoria de seu amigo íntimo David Hume, que seria consistente com seu esquema analítico.

Dos escritos de David Ricardo também podemos argumentar que ele pensava em termos de uma moeda neutra. Devemos levar em consideração que apesar de não viver em uma época tão distante da de Smith, a institucionalidade havia mudado. Em 1797, as notas bancárias na Inglaterra deixaram de serem conversíveis em ouro após crises financeiras.

Dois dos autores neoclássicos pesquisados, Marshall e Fisher, costumavam pensar em termos da famosa teoria quantitativa da moeda (TQM), que defenderia a neutralidade monetária. Mas ao se aprofundar nos escritos de Marshall, vemos que sua análise dos ciclos creditícios culmina na não-neutralidade da moeda. $\mathrm{E} o$ economista americano Irving Fisher claramente deixa de lado a TQM em seu ensaio "The debt-deflation theory of great depressions" de 1933, evidenciando o efeito deletério que a deflação (queda dos preços monetários) causa nas dívidas, na produção e no emprego.
Wicksell, outro neoclássico, deixou bem claro em sua argumentação as causas da não-neutralidade da moeda. O controle da oferta monetária é impossível num sistema bancário de reservas fracionárias e o crédito bancário interfere na relação poupança-investimento. Se a taxa de juros de mercado cobrada pelos bancos diferir da taxa natural de juros, a taxa teórica que equilibra poupança e investimento agregados, haverá flutuações no nível do investimento global.

Marx, ao notar a separação do processo de compra e venda de mercadorias no tempo através da moeda, abre espaço claro para crises de realização e insuficiência de demanda agregada. A não-neutralidade da moeda deriva da possibilidade de entesouramento pelos agentes.

Por fim, Keynes rejeita enfaticamente a ideia de neutralidade da moeda ao lançar sua teoria de que os agentes podem entesourar moeda buscando se proteger de eventos inesperados no futuro e especulação. A moeda teria essa capacidade pois seria um ativo líquido e seguro.

\section{Conclusões}

Podemos concluir que a investigação das ideias de pensadores clássicos pode ser bastante frutífera apesar dos aprimoramentos que elas sofrem com o passar dos anos.

Devemos notar também que cada pensador tentou refletir sobre a moeda dada a institucionalidade vigente em seu tempo.

\section{Agradecimentos}

Agradecemos ao CNPQ/PIBIC e ao SAE/ Unicamp pelo financiamento da bolsa que possibilitou essa pesquisa.

Fisher, I. "The debt-deflation theory of great depressions". Econometrica: Journal of the Econometric Society, p. 337-357, 1933.

Keynes, J.M. A Teoria geral do juro, da moeda e do emprego. São Paulo: Abril Cultural, 1988.

Marshall, Alfred. Money credit \& commerce. London: Macmillan, 1929

Marx, K. O capital: crítica da economia política. São Paulo, SP: Nova Cultural, 1985-1986. (Os economistas).

Ricardo, D. Princípios de economia política e tributação. 2a ed. São Paulo, SP: Nova Cultural, 1985. (Os economistas).

Smith, A. A riqueza das nações: investigação sobre sua natureza e suas causas. São Paulo, SP: Nova Cultural, 1996. 2 v. (Os economistas).

Wicksell, K. Lições de economia política. 2. ed. São Paulo, SP: Nova Cultural, 1988. (Os Economistas).

XXIV Congresso de Iniciação Científica da UNICAMP 